\title{
Analysis of the Situation Survey of Enterprises' Innovation Shouyu Chen
}

\author{
Zhejiang Yuexiu University of Foreign Languages, Shaoxing, P.R. China \\ chenshyu@zju.edu.cn
}

Keywords: Innovation; Manufacturing industry; Enterprise; Community Innovation Survey (CIS)

\begin{abstract}
This paper is a summary review of the survey of the manufacturing firms' innovation in Shaoxing city in China. The questionnaire consisted of 11 kinds of questions pertaining to product innovation, process innovation, innovation activity, sources of innovation, factors hampering innovation and so on. The questions in the questionnaire mainly come from the fourth Community Innovation Survey (CIS4) which conducted by Eurostat. The main results of the survey include: 1) the main type of product innovation is good innovation, which is always developed by a firm alone or together with other firms; 2) there are main innovation activities including acquisition of other external knowledge, in-house R\&D and training employee; 3) both customers and suppliers maybe are the most important information sources for innovation; 4) improved quality of product is the most important effect of product innovation while reducing labor costs per unit and reducing materials(energy) per unit are the most unimportant effect of process innovation; 5) innovation risk in the traditional manufacturing firms basically is moderate.
\end{abstract}

\section{Introduction}

The importance of innovation as a main determinant of sustainable competitive advantage in the traditional manufacturing industry is undisputable among economists and policy makers, especially on the background of the structural shift from resource-based economies to high value-added economics. In EU countries, EUROSTAT co-ordinated the first Community Innovation Survey (CIS) among European manufacturing firms in 1993 in order to collect firm-level data about innovation activities, and there had been four times surveys during 1993-2008. The questionnaire used in CIS was designed according to the guidelines contained in the OECD's Oslo Manual. In 2008, U.S. Department of Commerce and U.S. Census Bureau conducted a business R\&D and innovation survey [1]. The above two surveys' data make policy makers a deeper understanding of the innovation states in firms, and then it contributes to produce desirably public policy.

It is unquestionable that on the basis of the data of innovation activities in firms, policy makers as well as industry and academic data users could produce meaningful results. Based on this objective, we conducted a survey of innovation in manufacturing firms in Shaoxing city in May 2013. Our questionnaire consists of 11 kinds of questions pertaining to product innovation, process innovation, innovation activity, sources of innovation, factors hampering innovation, and so on. The questions come from the fourth Community Innovation Survey (CIS4) which conducted by Eurostat [2]. This survey collected information about product and process innovation. A total of 550 questionnaires were sent to people who had engaged in innovation project management at least 3 years. A total of 132 people responded to the survey (24\%), and 104 returned copies were valid (including 3 uncompleted copies), which come from textile industry (34 firms) and machinery manufacturing industry (28 firms) and other industries (42 firms). This article is a brief summary of the survey.

\section{Product and Process Innovations}

An innovation is a new or significantly improved product (good or service) introduced to the market or the introduction within an enterprise of a new or significantly improved process. In our survey, a product innovation is the market introduction of a new good or service or a significantly improved good or service with respect to its capabilities, such as improved software, user friendliness, 
components or sub-systems, and a process innovation is the implementation of a new or significantly improved production process, distribution method, or support activity for developing goods or services.

According to the Table 1, we find there are $83(79.8 \%)$ of respondents who had produced new or significantly improved goods, and 63(60.6\%) of respondents who had provided new or significantly improved services. $46(44.2 \%)$ of respondents' product or service innovations are mainly developed by one enterprise or within its group, 38(36.5\%) of respondents' innovations are produced by cooperating with other enterprises or institutions and $16(15.4 \%)$ of these innovations mainly come from other enterprises or institutions. From the data above, the number of good innovations is more than that of service innovations, and nearly $1 / 2$ innovations are done by one enterprise or within its group.

According to the results of survey of process innovation, there are $79(76 \%)$ of respondents had introduced new or significantly improved methods of manufacturing or producing goods or services, $61(58.7 \%)$ of respondents had adopted new or significantly improved logistics, delivery or distribution methods for inputs, goods or services, and 60(57.7\%) of respondents had put to use new or significantly improved supporting activities for processes, such as maintenance systems or operations for purchasing, accounting, or computing. Almost half of these process innovations (50 respondents, $48.1 \%$ ) are developed by one enterprise together with other enterprises or institutions, only $33(31.7 \%$ ) or $18(17.3 \%$ ) are developed by one enterprise (group) alone or other enterprises (institutions).

Table 1 The type of innovation and developer

\begin{tabular}{|c|c|c|c|c|c|}
\hline & Yes & No & $\begin{array}{l}\text { Type of } \\
\text { innovation }\end{array}$ & $\begin{array}{l}\text { Who developed these } \\
\text { innovation } \\
\text { Your firm together with } \\
\text { other } \\
\text { Or group otherfirms }\end{array}$ & $\begin{array}{l}\text { product } \\
\text { mainly } \\
\text { firms }\end{array}$ \\
\hline $\begin{array}{l}\text { Goods innovation } \\
\text { Services } \\
\text { innovation }\end{array}$ & $\begin{array}{l}83(79.8 \%) \\
63(60.6 \%)\end{array}$ & $\begin{array}{l}21(20.2 \%) \\
41(41 \%)\end{array}$ & $\begin{array}{l}\text { Product } \\
\text { innovation }\end{array}$ & $\begin{array}{ll}46 & 38 \\
(44.2 \%) & (36.5 \%) \\
& (15.4 \%)\end{array}$ & 16 \\
\hline $\begin{array}{l}\text { Methods of } \\
\text { manufacturing } \\
\text { Logistics, } \\
\text { delivery } \\
\text { or distribution } \\
\text { Supporting } \\
\text { activities }\end{array}$ & $\begin{array}{l}79 \\
(76 \%) \\
61 \\
(58.7 \%) \\
60(57.7 \%)\end{array}$ & $\begin{array}{l}25 \\
(24 \%) \\
42 \\
(40.4 \%) \\
44(42.3 \%)\end{array}$ & $\begin{array}{l}\text { Process } \\
\text { innovation }\end{array}$ & $\begin{array}{ll}33 & 50 \\
(31.7 \%) & (48.1 \%) \\
& (17.3 \%)\end{array}$ & 18 \\
\hline
\end{tabular}

\section{Innovation Activities}

As shown in Table 2, acquisition of advanced machinery, equipment and computer hardware or software, in-house $\mathrm{R} \& \mathrm{D}$, training are mainly three kinds of innovation activities, respectively received 83, 82, 80 respondents from all 101 respondents. Purchase or licensing of patents and non-patented inventions, know-how, and other types of knowledge from other enterprises or organizations are the lowest agreement (60 respondents) of all innovation activities. Activities for the market preparation and introduction of new or significantly improved goods and services, including market research and launch advertising, which aren't gained enough attention, only 64 respondents supported them. 
Table 2 The enterprises' innovation activities

\begin{tabular}{|c|c|c|c|c|c|c|}
\hline $\begin{array}{l}\text { In-house } \\
R \& D\end{array}$ & $\begin{array}{l}\text { Extramural } \\
R \& D\end{array}$ & $\begin{array}{l}\text { Acquisition } \\
\text { of } \\
\text { machinery, } \\
\text { equipment, } \\
\text { and } \\
\text { software }\end{array}$ & $\begin{array}{l}\text { Acquisition } \\
\text { of other } \\
\text { external } \\
\text { knowledge }\end{array}$ & Training & $\begin{array}{l}\text { Market } \\
\text { Introduction } \\
\text { Of } \\
\text { innovation }\end{array}$ & $\begin{array}{l}\text { Other } \\
\text { Preparation }\end{array}$ \\
\hline $\mathrm{N}$ & $\mathrm{Y}$ & $\begin{array}{ll} \\
\end{array}$ & $\mathrm{N}$ & $\mathrm{Y}$ & $\mathrm{N}$ & $\mathrm{Y}$ \\
\hline $82 \quad 19$ & $55 \quad 46$ & $83 \quad 18$ & $60 \quad 41$ & $80 \quad 21$ & $\begin{array}{r}64 \\
37 \\
\end{array}$ & $74 \quad 27$ \\
\hline
\end{tabular}

\section{Sources of Information}

In all sources of innovation, as shown in Table 3, clients (customers) (high: 59 respondents) and suppliers (high: 47 respondents) are the most important information sources for innovation activities, these results always are confirmed by literatures in previous researches [3][4]. However, institutions sources, including universities, public research institutions, maybe not play their important roles in the enterprises' innovation, 16 respondents hadn't used their information, or the enterprises perhaps neglect or disvalue the institutions' information sources. Besides, we can learn from Table 3, competitors or other enterprises in the same sector are regarded as a vital source of innovation (high: 53 respondents), it maybe imply that both innovation and imitation usually take place among competitors.

Table 3 Sources of innovation in enterprise's innovation activities

\begin{tabular}{|c|c|c|c|c|c|}
\hline $\begin{array}{l}\text { The number of responses Degree of important } \\
\text { Information source }\end{array}$ & High & Medium & Low & $\begin{array}{l}\text { Not } \\
\text { used }\end{array}$ & Total \\
\hline Internal & & & & & \\
\hline $\begin{array}{c}\text { Within your enterprise or enterprise group } \\
\text { Market sources }\end{array}$ & 37 & 48 & 10 & 6 & 101 \\
\hline $\begin{array}{l}\text { Suppliers of equipment, materials, component, } \\
\text { software }\end{array}$ & 47 & 45 & 5 & 4 & 101 \\
\hline Clients or customers & 59 & 38 & 4 & 0 & 101 \\
\hline Competitors or other enterprises in your sector & 53 & 36 & 7 & 4 & 100 \\
\hline $\begin{array}{l}\text { Consultants, commercial labs, private } R \& D \\
\text { institutes }\end{array}$ & 13 & 46 & 31 & 11 & 101 \\
\hline $\begin{array}{l}\text { Institutional sources } \\
\text { Universities or other higher education } \\
\text { institutions } \\
\text { Government or public research institutes } \\
\text { Other source }\end{array}$ & $\begin{array}{l}6 \\
9\end{array}$ & $\begin{array}{l}34 \\
33\end{array}$ & $\begin{array}{l}45 \\
43\end{array}$ & $\begin{array}{l}16 \\
16\end{array}$ & $\begin{array}{l}101 \\
101\end{array}$ \\
\hline Conferences, trade fairs, exhibitions & 32 & 47 & 15 & 7 & 101 \\
\hline $\begin{array}{l}\text { Scientific journals and trade/technical } \\
\text { publication }\end{array}$ & 10 & 23 & 50 & 18 & 101 \\
\hline Professional and industry associations & 20 & 33 & 29 & 19 & 101 \\
\hline
\end{tabular}

\section{Effects of Innovation}

Innovation activities produce high performance for the enterprises in products, processes or other fields, as shown in Table 4. In favor of putting more resources into product innovations, consequently the effects of product innovation (high: 51, 38 or 64 respondents) are more positive than these of process innovation (high: 39, 39, 28 or 26 respondents).

Improved quality of product (high: 64 respondents) is the most important effect of product innovation among the three kinds of product oriented effects. Improved flexibility and capacity of production (high: both 39 respondents) are the mainly two results in process innovations' effects. 
However, according to the Table 4, process innovation plays limited role in reducing labor costs per unit or reducing materials and energy per unit, the number of responses to low effect is 29 or 19 respectively, there are even 6 respondents who admitted that it hadn't been relevant to reduce materials and energy consumed.

Table 4 Effects of innovation

\begin{tabular}{|c|c|c|c|c|c|}
\hline $\begin{array}{l}\text { The number of responses Degree of observed effect } \\
\text { Effects of innovation }\end{array}$ & High & Medium & Low & $\begin{array}{l}\text { Not } \\
\text { relevant }\end{array}$ & Total \\
\hline Product oriented effects & & & & & \\
\hline Increased range of goods or services & 51 & 46 & 2 & 2 & 101 \\
\hline Entered new markets or increased market share & 38 & 53 & 9 & 1 & 101 \\
\hline $\begin{array}{l}\text { Improved quality of goods or services } \\
\text { Process oriented effects }\end{array}$ & 64 & 34 & 1 & 2 & 101 \\
\hline $\begin{array}{l}\text { Improved flexibility of production or service } \\
\text { provision }\end{array}$ & 39 & 59 & 3 & 0 & 101 \\
\hline $\begin{array}{l}\text { Increased capacity of production or service } \\
\text { provision }\end{array}$ & 39 & 53 & 7 & 2 & 101 \\
\hline Reduced labor costs per unit output & 28 & 44 & 29 & 0 & 101 \\
\hline $\begin{array}{c}\text { Reduced materials and energy per unit output } \\
\text { Other effects }\end{array}$ & 26 & 50 & 19 & 6 & 101 \\
\hline $\begin{array}{l}\text { Reduced environmental impacts or improved } \\
\text { health }\end{array}$ & 38 & 52 & 9 & 2 & 101 \\
\hline Met regulatory requirements & 36 & 54 & 10 & 1 & 101 \\
\hline
\end{tabular}

Besides effects of both product and process oriented, innovation activities play key roles in reducing environmental impacts or improved health and meeting regulatory requirements, reference to Table 4.

\section{Innovation Risk}

The three kinds of the innovation determinants are examined by nine questions. Here it seems the vast majority of respondents had experienced all of these risk factors. The approximate half of respondents feel that their organizations' innovation is in the medium risk environment, and high or low risk is recognized respectively almost $25 \%$, as shown in Table 5. Innovation risk in the traditional manufacturing firms basically is moderate.

In all of 9 risk factors, the cost of innovation is the vital risk factor; there are 39 respondents who agreed to high importance. Lack of funds or difficulty in finding cooperation partners is relatively unimportant because 13 or 15 respondents don't experience them and only 20 or 16 respondents in all of 104 respondents give them high importance.

The enterprises in high-tech industries experience higher innovation risk, by contrast, the firms' innovation risk in traditional manufacturing industries maybe lower. However, innovation risks in traditional manufacturing industries are unique [5] and the cost of the failure in innovation is also much expensive, innovation risk management should be gotten enough attention. 
Table 5 Factors hampering innovation activities

\begin{tabular}{|c|c|c|c|c|c|}
\hline $\begin{array}{l}\text { The number of responsex } \\
\text { importance }\end{array}$ & High & Medium & Low & $\begin{array}{l}\text { Factor not } \\
\text { experienced }\end{array}$ & Total \\
\hline \multicolumn{6}{|l|}{ Risk factors } \\
\hline Cost factors & & & & & \\
\hline $\begin{array}{l}\text { Lack of funds within your enterprise or } \\
\text { group }\end{array}$ & 20 & 51 & 20 & 13 & 104 \\
\hline $\begin{array}{l}\text { Lack of finance from sources outside your } \\
\text { enterprise }\end{array}$ & 20 & 53 & 22 & 9 & 104 \\
\hline $\begin{array}{l}\text { Innovation costs too high } \\
\text { Knowledge factors }\end{array}$ & 39 & 49 & 14 & 2 & 104 \\
\hline Lack of qualified personnel & 25 & 55 & 20 & 4 & 104 \\
\hline Lack of information on technology & 24 & 56 & 18 & 6 & 104 \\
\hline Lack of information on markets & 26 & 49 & 24 & 5 & 104 \\
\hline $\begin{array}{l}\text { Difficulty in finding cooperation partners for } \\
\text { innovation }\end{array}$ & 16 & 45 & 28 & 15 & 104 \\
\hline Market factors & & & & & \\
\hline Market dominated by established enterprises & 16 & 43 & 36 & 13 & 104 \\
\hline $\begin{array}{l}\text { Uncertain demand for innovative goods or } \\
\text { services }\end{array}$ & 17 & 45 & 34 & 8 & 104 \\
\hline
\end{tabular}

\section{Conclusion}

The importance of innovation is undisputable. In this line, we should pay attention to know about the present of manufacturing firms' innovation by conducting deep and overall survey, further develop appropriate policies to promote the abilities of firms' innovation.

In our survey, the summary of results includes: 1) the main innovation type is goods innovation, which are always developed by a firm alone or together with other firms; 2) there are mainly innovation activities including acquisition of other external knowledge, in-house R\&D and training employee; 3) customers or suppliers maybe are the most important information sources for innovation; 4) improved quality of product is the most important effect of product innovation and reducing labor costs per unit or reducing materials and energy per unit is the least important effect of process innovation; 5) innovation risk in the traditional manufacturing firms basically is moderate.

Because of the limited samples in the survey, the conclusions above should be challenged by other researches; we hope many high-quality surveys of innovation could be produced.

\section{References}

[1] Information on http://www.census.gov

[2] Information on http://epp.eurostat.ec.europa.eu/portal/page/portal/eurostat/home

[3] L. Santamaría, M.J. Nieto and A. Barge-Gil: Research Policy, Vol.38 (2009) No.3, p.507-517.

[4] H. Hirsch-Kreinsen, D. Jacobson: Innovation in low-tech firms and industries, Cheltenham, UK: Edward Elgar 2008.

[5] H. Hirsch-Kreinsen: Industry \& Innovation, Vol.15 (2008) No.1, p.19-43. 